\title{
Realization Strategy of Budget Allocation to Disseminating of Development Infomation
}

\author{
Tarmidzi, Sahri, Hadi Mahmudi \\ Magister Program of Economics, Mataram University \\ Email: adzipluss@gmail.com
}

Received: August 7, 2017; Accepted: November 25, 2017; Published: February 2, 2017

Permalink/DOI: http://dx.doi.org/10.17977/um002v10i12018p001

\begin{abstract}
The objectives of this study is to know the strategy of realization for budget allocation of 2016 for disseminating of development information in news and communication Information Division, especially in Publication and Media Relation Sub Division at Public Relation and Protocol Bureau, Provincial Secretariat of West Nusa Tenggara (NTB). This study uses descriptive qualitative approach and tends to find a meaning from data obtained from the result of a research. It is intended to describe the description of existing data or theories and the resulting findings. In this case, the researchers collected data by conducting in-depth interviews and the use of information access test methods of eleven informants. The results show that there are limitations of publication budget on Sub Division of Publication and Media Relations at Public Relations Bureau and Protocol Provincial Secretariat of West Nusa Tenggara, the inappropriate use of the strategy, the lack of harmony of internal relations both within the environment of public relations officials themselves and with the media crew, the presumption that the Trip Press budget is in vain, less than the maximum use of media Internal and outdoor media.
\end{abstract}

Keywords: Realization Strategy, Budget, Information and Development JEL Classification: G31, H73

\section{INTRODUCTION}

The Law No. 17 of 2003 on state finance is the beginning of regional budgeting reform in Indonesia. This budgeting reform raises a new paradigm in budgeting. That is the budgeting paradigm that put forward the principles of public accountability, public participation, and budget transparency (Sopanah \& Wahyudi, 2010; Riristuningsia et al., 2017). The budget should be managed with performance-oriented approaches, the principles of efficiency and effectiveness, justice and welfare, and in accordance with budgetary discipline and implementation of budgetary reforms that promote public accountability, community participation, and transparency requires good internal and external control and can be accounted (Mardiasmo, 2004; Mihaui et al., 2010).

In the next stage of the budget management process, implemented by all levels of government in Indonesia from the central government, provincial and district/city governments, even sub-districts and villages, refers to similar systems and mechanisms. In the regions since 2007, the management of the regional budget refers to the provisions of the Minister of Home Affairs Regulation No. 13 
of 2006 on Guidelines for the Management of Regional Finance. These guidelines are also adopted to the smallest unit in the Regional Device Work Unit (SKPD). It is applied also to the Public Relations Bureau and Protocols that manage the budget of publication or dissemination of development information.

Public Relations and Protocol Bureau has a strategic position in bridging communication between government and society (Posner \& Park, 2007). Moreover, in the current era of globalization, communication, and information, the role of public relations institution becomes very important considering its function as a government mouthpiece or bridge to communicate government policy to the public, conveying development information, and government performance (Curristine et al., 2007). As a spearhead, public relations is required to have the ability to face the challenges and changes of the times very quickly especially facing the development of technology, information, and communication. To improve the ability, public relations tools must master information and communication technology, including social media so as to know the needs of the public and more importantly, public relations must establish synergy and cooperation with journalists, in order to control the information submitted to the public (Canfield, 1964).

Minister of Communication and Information, Rudiantara in Public Relation Thematic Forum with the theme Strengthening Institutional Public Relations of Central and Local Government to Support Government Public Relations Function (GPR) reminded public relations should change the pattern of approach to society, that is from the old way to the more participative modern way. In addition, public relations should invite the community to be part of the process so that there is an emotional connection with public relations, and the community will feel have responsibility and do sharing more concern. Government public relations is required to improve the management and information services as well facilitate access easily the information for the community.

In order to convey the information, the existence of information technology is needed as a means of supporting the publication and communication to be more effective. Information technology can provide space for public relations practitioners in realizing the goals to be achieved. From 7.4 billion people earth's population, there are about 3.4 billion that use information technology through the internet network (Sanou, 2015). While the data from We Are Social (Singapore social marketing agency website) noted that until January 2017 there are 6 countries that have high enough digital population in Asean namely Indonesia, Malaysia, Philippines, Singapore, Vietnam, and Thailand. For Indonesia itself, from 259.1 million population, the internet users are 88.1 million people, active social media users 79 million, 326.3 million mobile phone users. This data increased by 15 percent in the past year (Kemp, 2017).

Even though the use of information technology is cheap, it still requires a budget. Especially if using conventional media such as print media would require a larger budget. However, the size of the budget has not been effective enough to increase knowledge. For example, the realization of publication budget of the development program in NTB Province managed by Bureau of Public Relations and Protocol of Regional Secretariat of NTB about Rp 3.5 billion more, has not been effective enough to increase recognition and knowledge to main 
development actors in NTB, like Governor Muhammad Zainul Majdi. His popularity is still below Ridwan Kamil, Mayor of Bandung, Tri Rismaharini Mayor of Surabaya, Basuki Cahya Purnama Governor of DKI Jakarta. Similarly, the development program offered has not been widely known by the public in NTB itself. This raises the question whether this is due to an inadequate budget or a misleading realization strategy for the use of its public budget? Referring to the above background, the authors are interested to conduct in-depth research on the strategy of realization of the use of publication budget which is carried out by the Publication and Information Communication Division on the Sub Division of Publications and Media Relations at Public Relations and Protocol Bureau Provincial Secretariat of West Nusa Tenggara. Therefore the formulation of the problem in this study is how the strategy of budget allocation in Sub Division of Publication and Media Relations, News and Information Communication Division at Public Relations and Protocol Bureau of Provincial Secretariat of NTB to disseminate development information? Based on the formulation of the problem, the purpose of this study is to analyze the budget use strategy in the Sub Division of Publication and Media Relations, Information and Communication Information Division on Public Relations and Protocol Bureau Province NTB for the dissemination of information on development programs.

\section{LITERATURE REVIEW}

\section{Meaning and Strategy Concept}

The pioneers of the strategy concept provide some important definitions of strategy. According to Chandler (1962) strategy is the determination of long-term goals and objectives of the company, the implementation of the action and allocation of resources needed to achieve the objectives that have been have been determined goals, objectives, and general policies/plans to achieve the goals set, By defining what business is run by the company, or that should be run by the company, or that should be run by the company.

A good strategy will help the organization in allocating its resources in the form of unique based on internal competence and the ability to anticipate the environment. According to Anthony et al. (1999) strategies can be defined as mission formulations and organizational goals, including action plans to achieve these objectives by explicitly considering competitive conditions and the effects of forces outside the organization directly or will not affect to organizational survival.

The term strategy derives from the Greek word strategies (stratus = military, and ag = lead), which means art or science to become a general. The strategy can also be interpreted as a plan for the sharing and use of military and material forces in certain areas to achieve certain goals. According to Stoner \& Gilbert (2001), the concept of a strategy can be defined based on two different perspectives: (1) from what perspective an organization wants to do (intends to do) and (2) from the perspective of what the organization ends up doing (eventually does).

Based on the first perspective, the strategy can be defined as a program to determine and achieve the organizational goals and implementation of its mission. That is, that managers play an active, conscious and rational active role in formulating an organizational strategy. While based on the second perspective, the 
strategy is defined as the pattern of responses or the organization's response to its environment over time.

\section{Information and Dissemination}

Information is the content contained in various forms of documents (library materials). Collection development is not based on physical form, but by content. Library not only stores books or library materials but also store information. In the research world, many information is available in the form of facts and data that require processing and analysis (Hermawan, 2006). According to Astuti (2008), information is an idea, a fact, an imaginative work of a person who is communicated, increases the knowledge of the recipient of information, reduces uncertainty, thereby increasing the confidence of the recipient of information and can make decisions, as well as in various formats. The information is presented in written form, speech, picture, or recorded symbols. The source of information is data. Data is a plural form of general data form or data item. Data is a fact that describes an event of real events and unity. Genesis is something that happens at a certain moment.

An information will be valuable when its benefits are more effective than the cost to get it. The usefulness of information is to reduce the uncertainty in the decision-making process of a situation. While Information Function according to Sutanta (2004) mentioned some of the functions of information are: (1) Increasing knowledge. By information, the knowledge of the recipient will be increased so that it can be used for consideration in decision making; (2) Reduce uncertainty. By information, what will occur can be predicted. So that, it can reduce uncertainty in decision making; (3) Reducing the risk of failure. By presence of predicted information about what will happen, it will assist in anticipatory measures so that the risk of failure will be reduced by appropriate decision making; (4) Reducing unnecessary diversity/variation in the presence of information will cause the diversity of opinions to be reduced so that the decisionmaking process is more directed; (5) Provide standards, rules, measures, and decisions that determine the achievement of goals and objectives. With the necessary information will provide more targeted standards, rules, measures, and decisions to achieve goals and objectives that have been better defined based on information obtained.

The development of this information can be like education, knowledge, and entertainment. The role and function of this mass media to see from the content of message contained in a news is to fulfill three aspects that are expected by society that is for the benefit of society, society need, and public comfort (Hasanov et al., 2016). This mass media is an institution, that is as an institution or organization. Understanding the mass media itself is Channels of communication through newspapers, magazines, radio, television, film, which can reach a wide audience with information derived from institutions (Graham \& Weiner, 1996). Mass media is one tool in the process of mass communication because The mass media is able to reach a wider and relatively larger audience, heterogeneous, anonymous, its message is abstract and dispersed. Mass media themselves in the study of mass communication are often understood as devices organized to communicate openly and in distant situations to a wide audience in a relatively short time. 


\section{Budget, Function and Its Allocation}

Mardiasmo (2009) defines the budget as a statement about the estimated performance to be achieved over during a certain period of time expressed in financial size, while budgeting is the process or method for preparing a budget. From the above understanding, the budget is associated with basic management functions that include the functions of planning, coordination, and supervision. So if the budget is connected to basic functions of management then the budget includes the function of planning, directing, organizing and supervising each unit and organizational areas within the enterprise.

According to Supriyono (1989), budgeting is a financial planning company used as the basis of control (supervision) corporate finance for the period to come. The budget is a short-term plan that is prepared based on the longterm plan of activities that have been defined in the process of programming. Where the budget is prepared by management for a period of one year, which will bring the company to certain desired conditions with the resources specified.

Budgeting is a process or method for preparing a budget with a very complicated stage and contains a very strong political nuance because it requires discussion and ratification of representatives of the people in the parliament consisting of various delegates of political parties (Posner \& Park, 2007). In contrast to budgets in the private sector where budgets are part of the secret of a company that is closed to the public, on the contrary, the state budget must be confirmed to the public for input and criticism. The state budget is also an instrument of accountability for the management of public funds and the implementation of programs financed with public money (Cawford \& Helm, 2009). The budgeting process begins when strategic planning and strategy formulation have been completed. The state budget is the articulation of strategy formulation and strategic planning that has been made. The budgeting stage becomes very important because the budget is not effective and not performanceoriented will be able to thwart the plan that has been prepared.

The function of the budget is generally a tool to assist the management in the implementation, the function of planning, coordination, supervision as well as the work guidance in running the company for the intended purpose to (Mahmudi, 2007): (1) Planning Function: Planning is one of the management functions and this function is one of the functions of management and this function is the basis of the implementation of other management functions. Mahmudi (2007) provides an understanding of the planning as follows: Planning involves the act of selecting and linking facts and making and using future assumptions in terms of visualizing and formulating proposed activities that are deemed necessary to achieve desired results. From the above quotation, it is concluded that before the company performs its operations, the leadership of the company must first formulate what activities will be implemented in the future and the results to be achieved from those activities, and how to implement them. With the plan, the activities will be done well. (2) Supervision Function: Budget is one way of holding supervision within the company. Supervision is the efforts undertaken so that the previously prepared plan can be achieved. Thus supervision is to evaluate work performance and corrective action if necessary. The supervisory aspect is to compare between achievements with the budgeted ones, whether efficiency can be found or whether the managing managers have worked well in managing the company. The purpose 
of the oversight is not to find fault but to prevent and correct mistakes. Often the supervisory function is misunderstood as seeking the faults of others or as a means of imposing penalties on the purpose of supervision to ensure the achievement of corporate goals and plans. (3) Coordination Function: Coordination function requires the alignment of working acts of each individual or part of the company to achieve the goal. Thus it can be said that in order to create coordination a good plan is required, which can indicate the alignment of the plan between one part and the other. A budget that serves as a planning must be able to adjust the plans made for different parts of the company so that one plan of action will be aligned with the other. For that budget can be used as a means of coordination for all parts of the company, because all activities are interconnected between one part with the other part is set well. (4) Working Guidelines Functions: The budget is a systematic work plan developed and expressed in the monetary unit. Normally budgeting based on past experience and estimates in the future, then this can be a working guide for every part of the company to run its activities. The most important objective of the budget is for outside control, ie to limit the overall resources available to an agency and to prevent expenses on things or activities that are not permitted by law.

According to Supriyono (2000) Budget has several kinds of functions and benefits. The budget benefits include (1) Planning of organizational activities or responsibility centers in the short term. (2) Help coordinate short-term plans. (3) Communication tools plan to various central responsibility managers. (4) Tools to motivate managers to achieve their central responsibility objectives. (5) A tool for controlling the activities and assessing the achievement responsibility centers and their managers. (6) Educational tools for managers.

\section{METHOD}

This study uses descriptive qualitative approach and tends to find a meaning from data obtained from a research result. It is intended to describe the existing data or theories and the resulting findings. The word qualitative implies an emphasis on processes and meanings which is not been studied strictly or measurable in terms of quantity, quantity, intensity, or frequency. In this approach, researchers emphasize the nature of socially constructed reality as well as the close relationship between the researcher and the subject studied.

The researcher conducted in-depth interviews and the use of information access test methods. This research was conducted at the Governor's Office at the Bureau of Public Relations and Protocol of Regional, Provincial Secretariat of West Nusa Tenggara, Jalan Pejanggik No. 12 Mataram. This location was chosen because of a large number of budgets and the strategic role of public relations in the distribution of information on regional development in West Nusa Tenggara Province. The research object is the informant's knowledge about the strategy of using the spending budget of publication services of regional and national media for dissemination of development information managed especially by Sub Division of Publication and Media Relations in Public Relations Bureau and Protocol Provincial Secretariat of West Nusa Tenggara. The informants chosen in this study are the parties directly involved and in the process of budget management and have authority in allocating the budget in the Bureau of Public Relations and Protocol especially in the News and Information Communication 
Section on the use of budget services publications of regional and national media cooperation to disseminate development information.

The data collection procedure used in this research is 3 (three) consisting of observation, in-depth interview and document study. While the type of data used in this research is qualitative data derived from (1) the results of in-depth interviews to informants (primary data) informants who know in depth and involved in the use of expenditure budget services publications of regional and national media on the Bureau of Public Relations and Protocol West Nusa Tenggara Provinces to disseminate information on regional development and (2) secondary data obtained from Online Media and the official website of the West Nusa Tenggara Provincial government as well as the official website of the Public Relations Bureau and Protocol of West Nusa Tenggara Provinces as the official publication media of the Provincial Government of West Nusa Tenggara, Media Information and related research results.

\section{RESULT AND DISCUSSION}

From the research conducted in April-June 2017 at the Bureau of Public Relations and Protocol of Provincial Secretariat of West Nusa Tenggara, a number of research themes were developed, including (1) budget limitation and use strategies, (2) the importance of maintaining good relations (3) Media, (4) Publication by using Internal media and external media, (5) Improving the strategy of realization of budget allocation in the future. These 5 themes are then interpreted by analyzing the result in related themes. The analysis is reinforced by comparing the concepts, theories and research findings found by other researchers. The results and explanation of each cluster are as follows:

\section{Budget Limitations and Strategies for Use}

Budget allocation for the dissemination of development information available in the Publications and Media Relations Sub-Division of Public Relations and Protocol Bureau of West Nusa Tenggara Province in 2016 reached more than 3.5 billion Rupiah. Funds of this magnitude are focused for publication through print and electronic media both locally and nationally, and partly for press conferences. From the budget allocation of Rp. 3.5 Billion more, the proportion of the budget for local media by 60 percent while the national media by 40 percent.

In terms of budget use, the important role of bureaucracy can not be denied. To realize a single item of the budget is required coordination between bureaucracy in stages. In terms of budget planning, the Public Relations Bureau and Protocol should at least coordinate with the Local Government Budget Team (TAPD) and the General Administration Assistant. This coordination serves to check the financing associated with social marketing in the form of advertorial, rent news column and so on mainly through the print media. With other Regional Work Unit, more coordination is done in the realization stage of budget utilization. Especially for the financing of event publications that are strategic, urgent and require other Regional Work Unit contribution.

This is confirmed by some informants who stated that the realization of budget usage in Bureau of Public Relations is important to pay attention to cooperation aspect with other SKPD, for example in organizing "event". For events that have been planned generally not too difficult to be executed because 
the event has been accompanied by financing through Budget List of Public Relations Bureau. However, for events that are sudden and must be made quick decisions, usually the Public Relations Bureau executes itself without seeing the connection with other Regional Work Unit.

Related to the realization of budget usage, informants stated that if the publication budget in Public Relations Bureau is completely inadequate, then coordination with other Regional Work Unit is also intended to support the financing. While coordination for the publication of certain events is usually done with Regional Work Unit. Among other things, for example with the Department of Tourism and BPPD West Nusa Tenggara Province for the event Wonderful Lombok Sumbawa. Nevertheless, the Public Relation Bureau is not free of responsibility, especially in terms of control of the substance of its proclamation. In other circumstances, if the budget at the Public Relations Bureau is still available and required by other Regional Work Unit, then the Public Relations Bureau will help finance the publication. If not all can be published, then the dicover is usually partly.

Other informants added that budget constraints for disseminating development information can also be solved by utilizing Corporate Social Responsibility (CSR) funds or corporate social responsibility funds. So the Public Relations Bureau needs to coordinate and cooperate with private companies, stateowned and local enterprises. Budget constraints also make the PR Bureau selective in selecting published information content. In other words, according to informants, if the budget is limited then only information relating to the achievement of Regional Development Middle Range Plan targets are exposed. Especially strategic programs and leading sectors such as tourism, agriculture and supporting infrastructure.

In relation to the achievement of budget allocation, most informants said that the achievement was very good, even reaching 99 percent. For publication budget in Public Relations Bureau of Rp 3.5 billion more still too small so quickly realized. However, in order to realize it, the priority scale will be determined. If not many government events, usually low absorption. But if a lot of events, usually immediately absorbed. In the first quarter usually, the budget realization is still low, but eventually reach the target in the next quarter because, in addition to many events, it is well programmed in the Bureau of Public Relations so it can be executed on time and smoothly according to the set targets.

\section{The Importance of Cooperation and Good Relationship}

In order for the realization of the use of the budget goes well and on target, the executor of activities and all components within the organization must be able to cooperate and maintain good relations. This good relationship is with all the lines in the organization, such as superiors with subordinates. Indeed as an organization, there must be a problem between superiors and subordinates, between the leadership with the subordinates. But according to informants as members of the organization, professionalism must be above all. Thus the existing problem can be immediately resolved. If there is no good relationship and cooperation it is difficult to coordinate to realize the budget effectively.

Another informant affirms that relationships within the organization can not be forever good, there must be colors and dynamics. Already a human nature 
in relation there must be a good time sometimes bad, but all there is a reason. For example, in the event of planning activities, there is often a debate because planning is made suddenly and far from the commitment of the plan agreed with the leadership, in this case, the head of the Bureau of Public Relations and Protocol. While with the General Administration Assistant the working relationship is not directly with the staff at the Bureau but directly with the Bureau Chief.

In addition, good relationships and cooperation are not enough just to the internal organization. Good relations with outsiders such as Media Workers, other SKPD, and private parties should be done. This good relationship and cooperation are not solely for budgetary reasons. But in a broader context related to the achievement of goals and common interests. A good relationship with Regional Work Unit is needed because of the synergy to achieve regional development program objectives and achievement of Regional Middle Range Plan. Public Relations Bureau needs to absorb information from other Regional Work Unit and become government spokesman when dealing with media and society. Maintaining good relationships with the private sector and the community is also important so that they contribute to the success of regional development programs. In this case, the role of the Bureau of Public Relations is decisive.

\section{Trip Press and "Closer with Media"}

Strengthening the relationship between local government and media or journalists is an important thing given the strategic role of media in disseminating information development. Hence the strategy of "communicating with the media" is an important effort to make the use of limited information publishing budget more effective and efficient. According to some informants, if the relationship is well established with the media and journalists, the quantity and quality of information publication are more massive and positive for the local government while the cost is smaller.

One way to streamline the use of the budget is to provide an opportunity for media crews to conduct a press trip or a tour press out of the region. It is intended to provide different perspectives to the media in viewing development in other areas and provide input to the government how best to study other successful regional development models. But lately, the press trip is rare and not even done. There are various reasons put forward by informants. Among informants consider the press trip out of the area to waste energy because in addition to media outside the region have its own correspondent, which can be the positive image is another area. While the region itself lacks appreciation. The budget spent on these activities becomes unfavorable for the region. Other considerations need a huge cost to do that and the budget available in Public Relations Bureau is not adequate. The budget available is more prioritized for advertorial or column rental.

In the context of the use of the budget, particularly for news and advertorial costs according to a number of informants is necessary prudence because for the expenditure of each cost should pay attention to the credibility and coverage of media readers. The bigger the media circle, the more fulfilled the requirement to cooperate in the context of news and advertorial. In the regions, the 
choice of local media with a large category is still very limited. The most likely option is to cooperate with the national media.

But in this case still appears obstacles with the national media. A good friendship is not enough, local governments should be able to understand the tastes of the national media both in terms of the type of news that is displayed and the value of newsworthy of loading. So far the national media is less interested in government activities that are ceremonial because it is too small. In addition, the cost of advertorials in the national media is too expensive for local governments. With limited publicity budgets, local governments should be selective and full of consideration for page rentals or advertorials in the national media.

Another strategy prepared to maintain this relationship is to prepare a means to facilitate the media to access the required news, including preparing the Media Center as a meeting room of journalists who are scheduled once a week there is a coffee break with local leaders or depending on how the issue should be addressed. If the information conveyed strategically and importantly usually quickly responded to the media/journalists and Media Center is usually crowded.

\section{Publication by Using Internal and External Media}

Internal media in question here is the official website in the form of websites, official accounts in social media such as facebook, twitter, and Instagram and print media in the form of bulletins. Given the limited budget for the dissemination of information on development programs, this strategy of using internal media is the most plausible alternative. In addition to its wide range of readers, the cost is also minimal. Although there are obstacles for readers who are not able to access information technology facilities and internet network constraints, the presence of digital media is very vital today. Access speed and more information content are other advantages of this medium.

According to informants, the utilization of internal media requires managers skills in terms of creating content, taking notes of routine and detailed leadership activities, making reports in the form of releases twice a day. Websites and social media more easily and quickly disseminate information while bulletins or newsletters are usually made 2 weeks. For this management formed a management team or commonly called the media team who served as creators, online media managers, bulletin managers, newsletters and website managers. With this effort, the limited publication costs can be overcome as well as assist the outside media by sending the required information immediately.

Utilization of outdoor media as one of the strategies of realization of budget usage and facilities of information publication of development program has a strategic role. Outdoor media such as billboards, banners, and others are often used to promote events both nationally and regionally. Bureau of Public Relations and Protocol also coordinate with other Regional Work Unit in utilizing outdoor media. In each Regional Work, Unit is usually assigned to install banners or billboards in front of his office. So far the coverage of outdoor media has reached 56 points managed by 17 Regional Work Units in West Nusa Tenggara Province in the form of billboards and billboards of varying sizes.

However, its use has not been effective. This is because the intensity of the use, placement and substance of information and the intensity of its publication has not been done massively. Besides, the limited number of location placement 
becomes a separate problem. Currently, the Public Relations Bureau owns outdoor media with only 3 points which are located in West Nusa Tenggara Governor's Office. In addition to Public Relations Bureau a Protocol, the use of outdoor media is also available in the backup by the Department of Communications, Informatics, and Statistics as much as 12 points in 10 districts/cities as West Nusa Tenggara

\section{Improved Strategies for Realizing The Future Budgets Allocation}

In this case, some information assumes that there is still a problem in the realization of budget usage. The problem is more due to problems in the Internal Affairs Bureau. Among other things related to the problem in terms of activity planning and budget for the dissemination of information. In the context of the hierarchy of decision-making, it should be tiered starting from the Head of Sub Division, then to the Head of Section and finally to the Head of Bureau. The coordinating system must also be one language and not hierarchical. Informants also expect openness or transparency between staff in the internal Bureau of Public Relations and Protocol. Other informants expressed the problem, for example, there is still discrimination between the print media with electronic media. In press conferences, for example, if there are no printed media present, activities are canceled when there are online media and radio present in the event.

Other informants are more on the budget side. So far, the budget for information publication is still very limited, therefore informants suggested budget allocation in Bureau of Public Relations and Protocol need to be improved. It will be difficult to extend public knowledge access to development information if the budget provided for such purposes is limited. If publicity budgets are increased, publicity activities can be massive and can reach the wider public.

The informants also hoped for a better partnership between Media and Public Relations and Protocol Bureau. Such partnerships are not only in the context of publications, advertorials and page rentals. However, such partnerships are also related to information exchange, coordination, preparation of materials for information content, and access to development information. For the future, the Bureau of Public Relations and Protocol is also expected to pay close attention to the preparation of releases that are more touching substance and not merely ceremonial. Thus it is expected that the message conveyed can touch the problems and needs of the community, as well as the HR Bureau of Public Relations and Protocols, need improvement through training or workshop.

More technical informants expect Bureau of Public Relations and Protocols can prepare facilities and infrastructure related to the dissemination of information including the presence of media centers, provision of accommodation and transportation for journalists that cover activities of local government in a place far and costly, access to information and provision of adequate information such as Provision of Wi-Fi in Media Center, computer access special media information and so forth.

\section{CONCLUSION}

Budget available for the dissemination of information is very limited, it takes creativity in the strategy of realization of budget usage. In terms of realizing this budget is done intensive coordination of the Bureau of Public Relations and 
Protocol, Assistant General Administration and Local Government Budget Team (TAPD). If the scope of activities is related to other Regional Work Unit then the coordination will be done also with the Regional Work Unit such as the Tourism Office and the Regional Tourism Promotion Board. Subsequently, priority programs and separation of partners of publications were selected selectively. Except for urgent activities usually direct decision-making by the Bureau of Public Relations to be published. Cooperation and maintaining good relations is also a strategy that is not less important, especially in the internal organization of the Bureau of Public Relations and Protocol. In order for this limited publication budget to be realized effectively then Sub-Section Publications and Media Relations with other parts must collaborate and cooperate. The more so with the Head of Bureau of Public Relations and the Protocol of the line of responsibility, coordination, and cooperation is clear and must be done. But good relationships do not always last sometimes there are frictions and different views between sections even with. This is hindering the realization of the use of budget information dissemination of development.

Maintaining good relations with the media is also an important strategy to get around budget constraints. News can be done without any advertorial so that the cost of disseminating information can be suppressed and used effectively. The Trip Press is also done effectively and is no longer out of the region. The design of the trip press is transformed into bringing foreign journalists to West Nusa Tenggara to cover good things and promote West Nusa Tenggara out of the region this can support economic improvements such as from the tourism and agriculture sectors. But in 2016 partnership with the media is less than optimal because it is a limited budget. Another strategy that is not less important in streamlining the use of the budget for the dissemination of information development is to utilize internal media such as websites, social media official, bulletin, and newsletter. With a broader do not this media can function to deliver messages and news quickly and more massively. Especially with bulletins and newsletters for management in other parts then it needs cooperation and understanding on the part. While the use of outdoor media though there is but the intensity is less. Most informants expect increased budget allocations for the dissemination of development information. In addition, the improvement of supporting facilities and infrastructure for journalists' coverage activities is also expected to be provided by the government. These include official travel for coverage for journalists covering local government activities. The media also hope for better cooperation with the government in the future, including related to advertorial and information sharing.

\section{REFERENCES}

Anthony, W.P., Parrewe, P.L., \& Kacmar, K.M. (1999). Strategic Human Resource Management, Second Edition. Orlando: Harcourt Brace and Company.

Astuti, P.R. (2008). Meredam Bullying: 3 Cara Efektif Menanggulangi Kekerasan Pada Anak. Jakarta: PT. Grasindo.

Chandler, A. (1962). Strategy and Structure: Chapters in the History of the American Industrial Enterprise. MIT. 
Crawford, L. H., \& Helm, J. (2009). Government and governance: The value of project management in the public sector. Project Management Journal, 40(1), 73-87.

Curristine, T., Lonti, Z., \& Joumard, I. (2007). Improving Public Sector Efficiency: Challenges and Opportunities. OECD Journal on Budgeting, $7(1), 1-41$.

Graham, S. \& Weiner, B. (1996). Theories and principles of motivation. In D.C. Berlinger \& R.C. Calfee (Eds.)

Hasanov, F., Mikayilov, C., Yusifov, S., \& Aliyev, K. (2016). Impact of Fiscal Decentralization on Non-Oil Economic Growth in a Resource-Rich Economy. Eurasian Journal of Business and Economics, 9(17), 87-108.

Hermawan, A. (2006). Metode Penelitian. Jakarta: PT. Gramedia Widia Sarana Indonesia.

Kemp, S. (2017). Digital in Southeast Asia in 2017. Retrieved from https://wearesocial.com/special-reports/digital-southeast-asia-2017

Law No. 17 of 2003 on State Finances. Retrieved from https://www.kemenkeu.go. $\mathrm{id} /$ sites/default/files/pdf-peraturan/law\%20no\% 2017\%20of\%202003.pdf.

Mahmudi. (2007). Manajemen Kinerja Sektor Publik. Yogyakarta: UPP STIM YKPN.

Mardiasmo. (2004). Otonomi Daerah dan Manajemen Keuangan Daerah. Yogyakarta: Penerbit Andi.

Mardiasmo. (2009). Akuntansi Sektor Publik. Yogyakarta: Penerbit Andi.

Mihaui, D. M., Opreana, A., \& Cristescu, M.P. (2010). Efficiency, Effectiveness and Performance of the Public Sector. Romanian Journal of Forecasting, 4, 132-147.

Posner, P., \& Park, C. (2007). Role of Legislature in the Budget Process: Recent Trends and Innovations. OECD Journal on Budgeting, 7(3), 1-26.

Riristuningsia, D., Wahyunadi., \& Harsono, I. (2017). Public Participation in Rural Development Planning. Jurnal Ekonomi dan Studi Pembangunan, 9(1), 57-64.

Sanou, B. (2015). ICT Facts \& Figures. Retreived from https://www.itu.int/en/ITUD/Statistics/Documents/facts/ICTFactsFigures2 015.pdf.

Sopanah., \& Wahyudi, I. (2010). Pengaruh Akuntabilitas Publik, Partisipasi Masyarakat, dan Transparansi Kebijakan Publik Terhadap Hubungan Antara Pengetahuan Anggaran dengan Pengawasan Keuangan Daerah. Jurnal Ilmiah Hukum Legality, 1-28. Doi: https://doi.org/10.22219/ jihl.v0i0.277.

Stoner, F., \& Gilbert, J. (2001). Manajemen Strategi, Edisi Indonesia. Jakarta: PT. Gramedia.

Supriyono. (1989). Akuntansi Biaya: Perencanaan dan Pengendalian Biaya serta Pembuatan Keputusan. Yogyakarta: BPFE.

Supriyono. (2000). Akuntansi Biaya: Perencanaan dan Pengendalian Biaya serta Pembuatan Keputusan, Buku II Edisi ke-2. Yogyakarta: BPFE.

Sutanta, E. (2004). Sistem Basis Data. Yogyakarta: PT. Graha Ilmu. 